\title{
Editorial
}

\section{Special Issue: Civil and Military Airworthiness: Recent Developments and Challenges}

\author{
Kyriakos I. Kourousis
}

School of Engineering, University of Limerick, Limerick V94 T9PX, Ireland; kyriakos.kourousis@ul.ie

Received: 27 March 2020; Accepted: 31 March 2020; Published: 1 April 2020

Airworthiness, as a field, encompasses all those technical and non-technical activities required to design, certify, produce, maintain and operate safely an aircraft throughout its lifespan. The evolving technology, scientific and engineering methods and, most importantly, aviation regulation, offers new opportunities and creates new challenges for the aviation industry.

This Special Issue assembles a diverse selection of research and review papers on topics of interest to the modern industry practitioners and researchers. These topics span across the initial and continuing airworthiness spectrum, discussing problems in the broader thematic areas of aircraft maintenance [1-7], safety management [6,8], human factors [1,4,5], cost analysis [3,7,9], structures [7,10,11], risk assessment [2,4], unmanned aerial vehicles [8,12] and regulations [6,12].

Reflecting on the list of targeted themes, communicated through the call for papers [13], I was pleased to see that most have been covered in the Special Issue, as indicated with the italic format in Table 1. I trust the readers will enjoy this variety of high-quality research and review papers.

Table 1. Coverage of Special Issue's targeted theme areas, as indicated with the italic format.

\begin{tabular}{ll}
\hline \multicolumn{1}{c}{ Initial Airworthiness } & \multicolumn{1}{c}{ Continuing Airworthiness } \\
\hline $\begin{array}{l}\text { Aircraft and aeronautical components testing } \\
\text { and certification }\end{array}$ & $\begin{array}{l}\text { Safety and risk assessment in aircraft flight and } \\
\text { technical operations }\end{array}$ \\
\hline $\begin{array}{l}\text { Qualification and certification of new technologies, i.e., } \\
\text { supersonic transport aircraft, electric and hybrid } \\
\text { propulsion aircraft, etc. }\end{array}$ & $\begin{array}{l}\text { Reliability analysis of aircraft systems } \\
\text { and components }\end{array}$ \\
\hline Certification of systems specific to military aircraft & $\begin{array}{l}\text { Continuing airworthiness management practice in civil } \\
\text { and military aviation }\end{array}$ \\
\hline $\begin{array}{l}\text { Qualification and certification of additively manufactured } \\
\text { metallic and non-metallic safe/non-safety-critical } \\
\text { aircraft parts }\end{array}$ & $\begin{array}{l}\text { Development and optimization of aircraft } \\
\text { maintenance programmes }\end{array}$ \\
\hline $\begin{array}{l}\text { Advanced testing and computational techniques for } \\
\text { composite aircraft testing and certification }\end{array}$ & $\begin{array}{l}\text { Development and optimization of military aircraft } \\
\text { structural integrity (ASI) management programmes }\end{array}$ \\
\hline $\begin{array}{l}\text { Reliability engineering methodologies and practice in } \\
\text { aircraft design and engineering changes }\end{array}$ & $\begin{array}{l}\text { Effective and efficient inspection and sustainment } \\
\text { techniques for composite aircraft }\end{array}$ \\
\hline $\begin{array}{l}\text { Safety and risk assessment methodologies and practice in } \\
\text { aircraft development }\end{array}$ & $\begin{array}{l}\text { Human factors in aircraft maintenance and operations } \\
\text { Human factor considerations in aircraft design }\end{array}$ \\
\hline $\begin{array}{l}\text { Safety management effectiveness in flight and } \\
\text { technical operations }\end{array}$ \\
\hline $\begin{array}{l}\text { Quality management and optimization in aircraft } \\
\text { maintenance organisations }\end{array}$ \\
\hline $\begin{array}{l}\text { Aircraft technical and non-technical cost analysis and } \\
\text { estimation techniques }\end{array}$ \\
\hline
\end{tabular}


Funding: I have not received external funding.

Acknowledgments: I wish to thank all authors for their contributions.

Conflicts of Interest: I declare no conflict of interest.

\section{References}

1. Chatzi, A.V. The Diagnosis of Communication and Trust in Aviation Maintenance (DiCTAM) Model. Aerospace 2019, 6, 120. [CrossRef]

2. Aust, J.; Pons, D. Bowtie Methodology for Risk Analysis of Visual Borescope Inspection during Aircraft Engine Maintenance. Aerospace 2019, 6, 110. [CrossRef]

3. Bozoudis, M.; Lappas, I.; Kottas, A. Use of Cost-Adjusted Importance Measures for Aircraft System Maintenance Optimization. Aerospace 2018, 5, 68. [CrossRef]

4. Chionis, D.; Karanikas, N. Differences in Risk Perception Factors and Behaviours amongst and within Professionals and Trainees in the Aviation Engineering Domain. Aerospace 2018, 5, 62. [CrossRef]

5. Chatzi, A.V.; Martin, W.; Bates, P.; Murray, P. The Unexplored Link between Communication and Trust in Aviation Maintenance Practice. Aerospace 2019, 6, 66. [CrossRef]

6. Batuwangala, E.; Silva, J.; Wild, G. The Regulatory Framework for Safety Management Systems in Airworthiness Organisations. Aerospace 2018, 5, 117. [CrossRef]

7. Dong, T.; Kim, N.H. Cost-Effectiveness of Structural Health Monitoring in Fuselage Maintenance of the Civil Aviation Industry ${ }^{\dagger}$. Aerospace 2018, 5, 87. [CrossRef]

8. Tabassum, A.; Sabatini, R.; Gardi, A. Probabilistic Safety Assessment for UAS Separation Assurance and Collision Avoidance Systems. Aerospace 2019, 6, 19. [CrossRef]

9. Lappas, I.; Bozoudis, M. The Development of an Ordinary Least Squares Parametric Model to Estimate the Cost Per Flying Hour of 'Unknown' Aircraft Types and a Comparative Application ${ }^{\dagger}$. Aerospace 2018, 5, 104. [CrossRef]

10. Iliopoulos, A.; Jones, R.; Michopoulos, J.; Phan, N.; Singh Raman, R.K. Crack Growth in a Range of Additively Manufactured Aerospace Structural Materials. Aerospace 2018, 5, 118. [CrossRef]

11. Memmolo, V.; Boffa, N.D.; Maio, L.; Monaco, E.; Ricci, F. Damage Localization in Composite Structures Using a Guided Waves Based Multi-Parameter Approach. Aerospace 2018, 5, 111. [CrossRef]

12. Hirling, O.; Holzapfel, F. EASA's “Open” Category for Military UAS: Opportunities and Limitations in the Field of Airworthiness. Aerospace 2018, 5, 70. [CrossRef]

13. Special Issue "Civil and Military Airworthiness: Recent Developments and Challenges". Available online: https://www.mdpi.com/journal/aerospace/special_issues/airworthiness (accessed on 26 March 2020). 